\title{
Classroom Management: A Tool for Achieving Quality Secondary School Education in Nigeria
}

\author{
Osakwe, Regina N. ,** $^{*}$ \\ ${ }^{1}$ Department of Educational Administration and Policy Studies, Delta State University, \\ Abraka, Nigeria \\ *Correspondence: Tel: 803-501-0236 E-mail: nonyeosakwe@yahoo.co.uk
}

Received: February 10, $2014 \quad$ Accepted: March 11, $2014 \quad$ Published: May 12, 2014

doi:10.5296/ije.v6i2.5616 URL: http://dx.doi.org/10.5296/ije.v6i2.5616

\begin{abstract}
This paper has highlighted the theoretical perspective of classroom management with regards to its concept, problems and roles of the classroom teacher in achieving a good learning atmosphere for quality secondary education. It also looked at the procedure of dealing with classroom management problems based on the three theoretical approaches of classroom management namely: the non-interventionist, the interventionist, and the interactionist. Finally, the paper recommends the techniques for promoting good classroom management for quality education to include: having leadership and management that will provide direction, planning, supervision, co-operation and co-ordination of teaching-learning process; teachers should have a positive role model; and there should be proper application of instructional materials and comfortable sitting arrangements to facilitate learning.
\end{abstract}

Keywords: teaching-learning process, classroom management, secondary schools, discipline, quality education 


\section{Introduction}

Secondary school level is the bridge between the primary and tertiary levels. The importance of secondary education is geared towards providing all primary school leavers with the opportunity for education of a higher level irrespective of sex, social status, religious or ethnic background; offer diversified curriculum to cater for the differences in talents, opportunities and future roles; provide trained manpower in the applied science, technology and commerce at sub-professional grades; develop and promote Nigerian languages, art and culture in the context of world's cultural heritage; inspire students with a desire for self improvement and achievement of excellence; foster National unity with an emphasis on the common ties that unite us in our diversity; raise a generation of people who can think for themselves, respect the views and feelings of others, respect the dignity of labor, appreciate those values specified under our broad national goals and live as good citizens; and provide technical knowledge and vocational skills necessary for agricultural, industrial, commercial and economic development (FRN, 2004). The underline principle here is that the secondary schools should be able to provide quality, secondary education to all those who can benefit from it. The realization of these aims and objectives hinges in many variables such as good classroom management, adequate teachers, availability and adequate utilization of teaching and learning materials, infrastructural/physical facilities and school inspection and supervision.

Quality education has significant impact and useful contribution to the area of human development, therefore secondary school students have right to receive an education of good quality which is associated with different academic and institutional factors. Researchers such as Mobegi, Ondigi and Oburu (2010), Digolo (2003) and Eshiwani (1993) suggested that a number of factors contribute to the establishment of quality education in secondary schools. They observed that the maintenance of factors such as curriculum, instructional materials, equipment, classroom/school management, supervision, teacher training and competencies of teachers are some of the indicators of quality education. Quality education is that education given to secondary school students in order to develop their cognitive, affective and psychomotor abilities and skills, and grow in school environments that are supportive and challenging which nurture them to become confident, have good self-esteem and willing to strive forward yet at the same time feel a sense of responsibility towards others in the society.

Despite the efforts to provide quality education, the secondary school system continues to face challenges that could compromise the quality of education provided. One of such challenges is poor classroom management. The quality of classroom management in our secondary school system appears below the expected standard because of infrastructural and human capital inadequacies. Classroom management task consists of planning lessons, providing a conducive learning environment, teaching students and perhaps the most daunting task of all, is appropriately responding to students' behavioral problems. This is a great task that teachers face on daily basis which require them to work diligently and continuously to maintain a positive classroom atmosphere. The ability of teachers to organize of their students is critical to achieving positive educational outcomes. 
Classroom management include all the efforts teachers make in the following areas, organizing the students, co-coordinating their activities, monitoring their behaviors, ensuring effective learning process, providing instruction through interactive communication, getting feedbacks from learners, preparing and utilizing instructional materials in facilitating learning, maintaining discipline among learners, evaluating learning outcome, ensuring that the problems of above average learners are being solved, relating on one to one basis with learners, being mindful of their basic needs, providing basic information to learners, assisting learners in developing coping skills, providing an exemplary behavior for learners to imitate, and generating interest among learners as well as reinforcing their performance through motivational techniques (Egbule, 2005).

Classroom teachers are known as classroom managers because of their roles in managing learning activities, instructional procedures, the prevailing attitudes, feeling and atmosphere in the classroom. Teaching and classroom management cannot be separated because effective classroom management is characterized by effective discipline, and discipline is seen as an instruction, training of the mind, and subjection to school rules and regulations. Though discipline may seem harsh and unpractical for students, it is the most essential element in securing effective classroom management and an excellent academic performance of students which leads to quality education.

\section{Concept of Classroom Management}

The classroom is an operational venue in schools which holds students together and offers them the opportunity of achieving the purpose of education, (Hill and Hill, 1990).It is a room in a school where a group of students or children are taught lessons. Thus, the classroom should be well managed and maintained to bring about healthy learning environment, relatively free from behavioral problems which goal should be to maintain a positive productive learning environment and quality performance. The quality of the physical environment, according to Edwards (1993), affects the performance of teachers as well as that of students.

Classroom management can be defined as the teachers' ability to co-operatively manage time, space, resources, students' roles and behaviors to provide a climate that encourages learning (Alberto and Troutman, 1986). Duke (1979) viewed classroom management as the provisions and procedures necessary to establish and maintain an environment in which instruction and learning can occur.

Classroom management according to David, (1996) involves a positive classroom environment, appropriate standards of behaviors for students, effective management of daily routines and instructions, and engaging the students in classroom activities throughout the lessons to ensure quality secondary education. The emphasis on classroom management therefore is dependent on components such as, an engaging curriculum, the teacher as a role model, students as responsible citizens, classroom management skills, robust instruction and working with resistance, conflict and stress. If any of this component is neglected, the whole 
process is compromised, leading to poor quality in education. Classroom management is the process of enhancing the learning environment, physical interaction between teachers and students, student to student, parents and others, stimulating and motivating children to learn to learning objectives, control and supervision throughout the school to facilitate and encourage co-operation in teaching and learning activities in the classroom smoothly, will as a result, improve the quality of students performance (Wisetrinthong, Sirisuthi and Weangsamoot, 2012)

Classroom management, therefore, could be seen as an integrant part of effective teaching which deters behavior problems through good planning, organizing and managing of classroom activities, good presentation of instructional materials and good teacher-student interaction aiming at increasing students' involvement and co-operation in learning to ensure quality secondary education.

Classroom management is an art and a science with many identifiable characteristics that result in smooth periods of learning, flexible enough to recognize what is needed and has the ability to keep control of the situation(s) that arise. Effective classroom management begins with mutual respect and interpersonal relationships and is vital to improve student achievement and teacher self-efficacy. It requires commitment to students and their learning, because a positive rapport with students is the foundation upon which classroom culture is built.

Effective classroom management is an essential ingredient that promotes and enhances good teaching-learning environment which eventually lead to quality secondary education. The teachers and other members of staff must co-operate to manage the classroom, students, non-human resources and the environment. Effective classroom management revolves around the teachers' attitudes, skills, desires, setting of expectations and positive actions. To improve classroom behavior and student social skills, teachers must conceptualize the process of teaching and understand classroom management principles for making professional decision on class management. A well-managed classroom should strike a balance between consistent disciplines and praise (Venkat Lakshmi, 2010).

\section{Problems of Effective Classroom Management}

In a school system, where good classroom management is lacking, there is likely to be chaos which affects the teaching-learning process, and the standard of students performance, hence a good teacher should be acquainted with such problems, be able to prevent and find solutions to such problems in order to promote quality secondary education. These problems are as follows:

The most crucial of all problems is overcrowded classroom which constitutes a serious problem in many school systems (Burnett, 1995) particularly in urban areas where space for new construction of classroom is at a premium and funding for such construction is limited. As a result, students find themselves trying to learn in overcrowded classrooms, where 60-80 students occupy a classroom as seen in some Delta State Secondary Schools. My experience 
as a classroom teacher in the 1990's showed that overcrowded classrooms lead to noise making and restlessness lose interest and lack concentration on their lessons. Teachers spend much time controlling and managing the students instead of teaching, thereby making the teaching-learning process cumbersome especially in group work and co-operative learning. Some recent studies (Schneider, 2002, Lewis, 2000) have linked teacher effectiveness and teacher attrition to the condition of the school in which they teach.

Arogundade and Bolarinwa (2011) in their study revealed that poor teacher-student relationship, poor motivation, inadequate physical facilities, and teacher's work environment in terms of conducive environment are major constraints to effective classroom management. Other problems of effective classroom management include the following:

Classroom Structure: Another problem is classroom structure which means the physical setting of the classroom. It constitutes management behavior problems due to inadequate number of furniture, lack of space between this furniture, inadequate chalkboard, poor ventilation and lighting, the size of the classroom and also the sitting arrangement.

Instructional Delivery Method: This has been identified as one of the major factors that constitute classroom management problems. The teacher who uses only one method of teaching without varying his methods makes the lesson boring and uninteresting to the students. Teacher's insufficient knowledge of subject matter and poor communication cause inappropriate behaviors and poor academic standard.

Lack of Teacher's Preparation: Many teachers have no comprehensive information to apply to the management of student's behavior problems in the classroom; instead they employ various ideas about discipline from disparate sources. Teacher training institutions which puts emphasis on pedagogical methods and content knowledge does not do much to ameliorate this situation. There should be a program/course on classroom management problems and their solutions in teacher training institutions so that such problems will be properly identified and handled. Thus, many teachers embark on their career without having mastered an effective approach to managing students in the classroom.

Some classroom management problems which are resultant effects of the above problems include absenteeism, noise making, rudeness, disobedience, naughtiness, truancy, restlessness, inattention, boredom, fighting (verbal and physical), sleeping, untidiness and refusal to do assignments.

\section{Teachers' Role in Preventing Classroom Management Problems for Quality Secondary Education}

Teachers and students sometimes perceive things in different ways and these differences in perception constitute a management problem. To reduce these differences, and in order to be effective, and promote quality teaching and learning, teachers must be proactive, facilitative and imaginative classroom managers, (Henson \& Eller, 1999). Thus, the under listed strategies will prevent classroom management problems: 


\section{Macrothink}

1) Providing instructions that use a variety of models, approaches and activities consistent with learning objectives because young students typically respond positively to stimulation and variety in the classroom. These activities make students to participate actively in the lesson, and increases their attention span and motivation.

2) Instruction should be free of ambiguous and vague terms and interruptions. The instruction should be made simple from known ideas to unknown.

3) Keeping thorough and realistic records of student's attendance and academic performances for the purpose of evaluation.

4) Knowing students names and calling them by their names will make them feel that they are part of the classroom organization.

5) Encouraging students to work co-operatively in groups such as laboratory activities or smaller group projects.

6) Monitoring students carefully and frequently so that misbehavior is detected early before it involves many students or becomes serious and redirecting the students to appropriate behavior by stating what the students should be doing citing the applicable procedure or rule, (Robert Kizlik, 2007).

7) Challenging learners to greater achievement by involving students in the self evaluating process.

8) Teachers can reduce inappropriate behaviors from problems in the physical environment by changing the sitting positions of the students that are likely to exhibit classroom behavior problems and ensuring that students can easily get access to instructional materials and activities, (Smith and Rivera, 1993). There should be proper seating arrangement in which the teacher is close to all the students in order to direct learning as well as circumvent any inappropriate behavior that will disrupt classroom activities. The teacher should also review the amount of furniture provided whether they are adequate or not for the student's population and classroom size.

9) Teacher's conscious modeling in terms of behavior will have positive impact on classroom management. This implies that the students will expect the teacher to be a role model (good example) of the expectations that he conveys. This is in line with the view of Mc Daniel, 2007 who opinionated that "values are caught not taught". Teachers who are courteous, prompt, enthusiastic, patient and organized provide examples for their students through their own behavior.

10) Involving learners in curriculum planning, and also keeping the curriculum interesting by varying presentation formats.

11) Probing into the students' background is a valuable step of solving classroom management problems. This is because student's indiscipline in school could arise from the home environment and training to which the students were exposed before coming to school. 
12) Rules, policies and procedures should be clearly stated and taught to the students.

\section{Dealing with Classroom Management Problems using the Theoretical Approach}

There are three theoretical approaches to the management problems namely, the non-interventionist, the interventionist, and the interactionist, (Levin and Nolan, 1991).

The non-interventionist approach, based on humanistic and psychoanalytic theories of development, suggests that the child develop from an inner unfolding of potential. The teacher's role is to facilitate this process by promoting strong, trusting relationship with children and helping them develop their problem solving abilities. The major goal of the non-interactionist approach is to enhance the personal growth and freedom of the individual, in the teaching-learning process in secondary schools.

The interactionist approach, based on behaviorist approach, suggests that children develop as a result of external environmental conditions such as reinforcement and punishment. The teacher's role in the classroom is to enforce rules and procedures, communicate these clearly to students and implement appropriate rewards and punishment for compliance or non-compliance respectively. The major goal of the interventionist approach is to maintain an orderly and productive classroom that promotes quality secondary education.

The interactionist approach, based on social, gestalt and developmental psychological theories view child's development as the interaction of inner and outer forces. The teacher's role is to understand student's behavior and to help students understand their own behavior and its consequences. The major emphasis of this approach is how the established rules and regulations can be obeyed by the students concerned.

\section{Techniques of Effective Classroom Management for Promoting Quality Secondary Education}

Effective classroom management requires proactive and reactive teachers in order to define and communicate their social and academic expectations to their students. Such involvements can motivate the students to obey and accept the school rules and regulations. Classroom management strategies are a crucial part of teacher's success in creating a safe and effective learning environment for student's quality secondary education. Therefore, teachers should know how to use and apply strategies that will allow and also help students to learn (Zuckerman, 2007).

Promoting quality secondary education through effective classroom management means creating an environment in which all students feel safe, respected and empowered with academic activities. Students will feel safe when they have the confidence that their ideas and opinions are valued, whether or not they are correct. The teacher must promote polite and respectful student interactions and address inappropriate student behavior in a positive manner. 
From experience, teachers in Nigerian secondary schools can apply the following classroom management techniques for quality secondary education:

- Plan their lessons using the scheme of work as a guide, and present lessons from known to unknown facts.

- Use proper introductory strategies to set student expectations at the beginning of every lesson and activity.

- Delegate specific responsibilities daily to students (e.g. collection of chalk, collection and distribution of books) and request for regular update and reports from such students.

- Use incentives to motivate students and provide counseling services for those with deviant behaviors.

- Teachers should strive to create love and trust for their students and also listen attentively to their complaints, ideas and suggestions.

- Arrange the classrooms and manage the few facilities provided for students usage.

- Treat students cases justly and equally without bias/partiality - set up a positive behavior for rewards and punishment system.

- Make rules and regulations simple and understandable, and be consistent in enforcing them.

In order to have an effective classroom management, Jones and Jones, (2012) suggested five main skills as follows:

- Developing a solid understanding of the students personal, psychological, and learning aspirations,

- Establishing positive student-teacher and peer relationships that aid students psychological needs,

- Using instructional methods that facilitate optimal learning by responding to students learning needs,

- Using organizational and group management methods that maximize students on task behaviors, and

- Using counseling and behavioral methods that involves students in examining and correcting their inappropriate behaviors.

Consequently, teachers should choose from a variety of strategies to meet the individual needs of their students for effective learning, discipline and control that enhance quality secondary education. 


\section{Conclusion}

There is no technique for classroom management that will totally overcome student behavior problems if the teacher does not provide an interesting, engaging program that allows each student to become actively involved. The study so far has focused attention on the various concepts, problems, approaches and techniques of effective classroom management for promoting quality secondary education. Efforts were made to highlight the role of teachers in classroom management. Effective classroom management significantly affects the climate, motivation, discipline, respect, goal achievement and academic performance of students in secondary school system.

\section{Recommendations}

Classroom management problems can be resolved through a variety of approaches and techniques, which the teachers should integrate systematically to promote quality secondary education. In this regard teachers and administrators should help the students manage and cope with their classroom management behavior problems that disrupt teaching-learning process.

Finally, apart from the professional training given to teachers, teachers should be counseled by stakeholders such as principals, senior teachers and inspectors of education that rewarding desirable behaviors is more effective than punishing undesirable behaviors. Teachers should also be advised to ignore inappropriate behavior while reinforcing competing incompatible but appropriate behaviors.

\section{References}

Alberto, P.A., \& Troutman, A.C. (1986). Applied behavior analysis for teachers. In K.T. Henson \& B.F. Henson \& B.F. Eller (1999:404) (Ed.); Educational Psychology for Effective Teaching, Wadsworth Publishing Company, USA.

Arogundade, B.B., \& Balarinwa, D.A. (2011). Teachers' work environment as correlate of classroom management in Ekiti state government secondary schools. Journal of Emerging Trends in Educational Research and Policy Studies (JETERAPS), 2(4), 234-238.

Burnett, Gray (1995). Overcrowding in urban schools Eric/Cue Digest Numbers 107, New York: Eric Clearing House on Urban Education. ED 384682.

David, W.C. (1996). Understanding and managing students problem behavior in schools: an integrative approach. Education Journal, 24(2), 15-28.

Digolo, O.D. (2003). Response to the paper entitled: "Education sector review: How far have we come since independence and what still needs to be done to meet the education needs of all kenyans”. Paper Presented in Education Conference. Nairobi: Government Press. 
Duke, D.L. (1979). Editors preface. In D.L. Duke (Ed.), Classroom management 78th yearbook of the national society for the study of education Part 2, Chicago: University Chicago Press.

Edwards, C. (1993). Classroom discipline and management. New York: Macmillan College.

Egbule, J.F. (2005). Methodology of guidance and counseling: Professional manual for counseling psychologist. Revised Edition, Benin City: Good news Express Communication.

Eshiwani, G.S. (1993). Education in kenya since independence. Nairobi: East African Educational Publishers Ltd.

Federal Republic of Nigeria (2004). National policy on education(4th Edition.). Lagos: Federal Ministry of Education NERDC 7-21.

Henson, K.T., \& Eller, B.F. (1999). Educational psychology for effective teaching, Wadsworth Publishing Company USA.

Hill, S., \& Hill, T. (1990). The collaborative classroom: A guide to co-operative learning. South Yarra, Victoria: Eleanor Curtain.

Jones, V.F., \& Jones, L.S. (2012). Comprehensive classroom management: Creating communities of support and solving problems. (10th edition). Prentice Hall: ISBN: 978-0132697088.

Levin J., \& Nolan, J. (1991). Principles of classroom management: A hierarchical approach. Engle Wood Cliffs, N.J. Prentice-Hall.

Lewis, M. (2000). Where children learn: facilities, conditions and students test performance in milwaukee public schools. ISSUETRAK, A CEFP Brief on Educational Facility.

McDaniel, Phi Delta Kappen (2007). Classroom management. Retrieved 22nd January, from http//www.honorlevel.com /x47xml

Mobegi, F.O., Ondigi, \& Oburu P.O. (2010). Secondary school head teachers' quality assurance strategies and challenges in gucha district, Kenya. Academic Journals-Educational Research and Reviews, 5(7), 408-414.

Robert Kizlik (2007). Classroom management and managing student conduct, effective praise guidelines and a few things to know about esol thrown in for good measure. ADPRIMA Instruction System http://www.adprima.com/managing.htm

Schneider, M. (2000). Linking school facility conditions to teacher satisfaction and success. National Clearing House for Educational Facilities.

Smith, D., \& Rivera, D. (1993). Effective discipline, (2nd Ed.) Austin, Tx: PRO-ED.

Venkat Lakshmi, H. (2010). Classroom management in integrated school setup. International Journal of Education Science, 2(2), 95-102. Kre Publishers, India. 
Wisethrinthong K., Sirisuthi C., \& Weangsamoot V. (2012). The development of classroom management system for the educational extension schools. European Journal of Social Sciences, 30(2), 313-320.

Zuckerman, J. (2007). Classroom management in secondary schools: A study of student teachers’ successful strategies. High Beam Research Inc., USA.

\section{Copyright Disclaimer}

Copyright reserved by the author(s).

This article is an open-access article distributed under the terms and conditions of the CreativeCommons Attribution license (http://creativecommons.org/licenses/by/3.0/). 